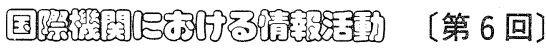

\title{
WIPO（世界知的所有権機関）
}

下道 晶久*1

\section{WIPO の概要}

\section{1 設立の目的と経緯}

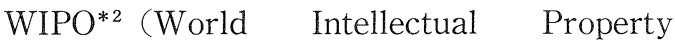
Organization : 世界知的所有権機関) は, 全世界 にわたって知的所有権の保護を促進するととも

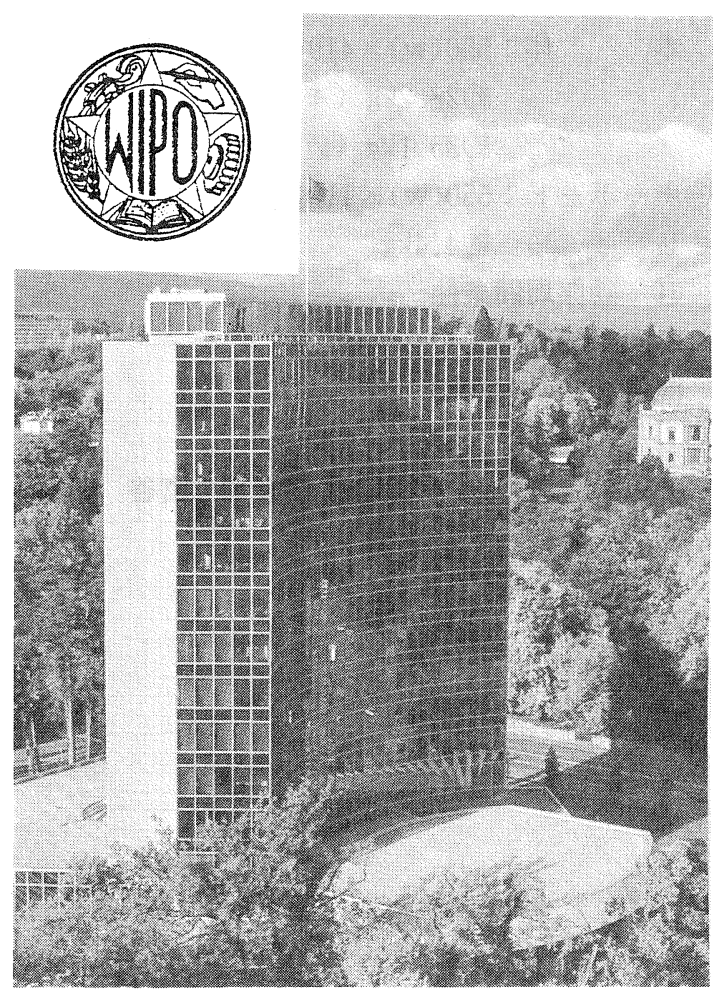

写真 1 WIPO 本部（スイス，ジュネーブ）
に, WIPO が管理する諸同盟（パリ同盟，ベルヌ 同盟等) 間の協力を確保することを目的として， 1967年 7 月14日ストックホルムで署名された「世 界知的所有権機関を設立する条約」に基づいて設 立された国際機関である。この条約は1970年 4 月 29日に発効し，1982年 3 月 1 日現在で加盟国数は 98か国である。

知的所有権は特許権, 商標権, 意匠権等の工業 所有権, および著作権の二つの主要部門から成っ ている。

WIPOの前身は，1883年に設立された「工業所 有権保護のための国際同盟（通称パリ同盟）」と， 「文学的及び美術的著作物保護のための国際同盟 (通称ベルヌ同盟)」の両事務局の合併により, 1893 年に設立された知的所有権保護国際合同事務局 (略称 BIRPI) である。WIPOの本部はスイスの ジュネーブに置かれて和り，1974年12月に国連の 第14番目の専門機関となった。

\subsection{WIPO の活動}

WIPO 設立条約にうたわれているWIPOの目 的は，以下のと新りである。

（i）諸国間の協調を通じ，掠よび必要な場合に は他の国際機関と協力して世界的規模での知 的所有権の保護を促進すること。

(ii) 知的所有権に関与る諸同盟間の行政的協力 を保障すること。

(i)に関してWIPOは, 新しい国際条約の締結と

*1 しもみち てるひさ 特許庁 審査官

*2 フランス語での略名は “OMPI” 
国内法の調整とを奨励している。つまり，WIPO は発展途上国に法技術的援助を与光, 情報を収集, 配布し，末た加盟国の間での国際登録その他の行 政的協力に関するサービスを行っている。

(ii)に関して，WIPO は，WIPOの事務局たる在 ジュネーブ国際事務局に諸同盟の行政事務を一本 化し，その各下部機関を通じこの事務を監督して いる。しかし，著作権と隣接権に関しては，一本 化は完全ではない。すなわち，万国著作権条約は UNESCO が管轄し，隣接権に関するローマ条約 の管理はUNESCO 挔よび国際労働事務局との協 力の下にWIPO が担当している。

さらに, WIPO は国連の専門機関として, 国連 憲章並びに国際連合の管理する条約および協定に 従い，とりわ壮，国連抢よびその機関，その他国 連システムの下にある機関の権限を尊重して創造 的な知的活動を助長し, 工業所有権に関する技術 の発展途上国への移転を容易にし，もってその経 済的，社会的打よび文化的発展を促進するため， 適切な行動をとる責任を負らている。

したがって，発展途上国のための活動を計画， 実行する上で, WIPO は創造的知的活動を奨励 し, 並びに経済的, 社会的抏よび文化的発展のた め, あらゆる種類の技術的, 科学的その他の情報 へのアクセス拉よびその選択, 適合执よび使用を 容易にすることに重点を置き，緊密化する国際協 力を指針として行動している。

\section{《WIPO が管理している同盟および条約》}

現在, WIPO が管理している同盟および条約は 以下のと拈りである。このうち日本が加盟してい るのは，パリ条約，IPC 同盟，PCT 同盟拉よびブ タペスト同盟である。

(a) 工業所有権の分野

(1)パリ条約 (工業所有権の保護に関する)

(2)マドリッド協定（商品に関する虚偽のまたは 䛊認を生じさせる原産地表示の防止に関す る)

(3)マドリッド同盟（標章の国際登録に関する）

(4)へーグ同盟(工業的意匠の国際登録に関する)
(5)ニース同盟（標章登録を目的とする商品およ びサービスの国際分類に関する)

(6)リスボン同盟（原産地名称の保護とその国際 登録に関する)

(7)ロカルノ同盟（工業的意匠の国際分類に関す る)

(8) IPC 同盟（特許分類の世界的統一の確立に関 する)

(9) PCT 同盟（発明保護が数か国で求められる 場合に抢ける国際発明保護出願の提出, 調査 および審査協力に関する)

(10) TRT 同盟（商標保護が数か国で求められる 場合に打ける国際出願の提出に関する)

(11)ブタペスト同盟（特許取得のための微生物寄 託の国際的承認に関する)

(b) 著作権抒よび隣接権の分野

(1)ベルヌ同盟（文学的美術的著作物の保護に関 する)

(2)ローマ条約（実演家，レコード著作者招よび 放送事業者の保護に関する)

(3)ジュネーブ条約（レコード無許諾複製に対す るレコード製作者の保護に関する)

(4)ブリュッセル条約（衛星により発信される番 組搬送信号の配送に関する)

(5) UPOV（植物新品種の保護に関する）

(c) まだ発効していないが，発効した際には WIPO により管理されることになるであろう 条約

(1)ウィーン協定（標章の図形要素の国際分類を 設立するための)

(2)ウィーン協定（タイプフェースの保護抢よび その国際寄託のための）

(3)ジュネーブ協定（科学的発見の国際登録に関 する)

(4)マドリッド多国間条約（著作権使用料の二重 課税に関する)

\section{3 国際事務局}

1.3 .1 組織と機能

国際事務局はWIPO の事務局であり，パリ，べ 


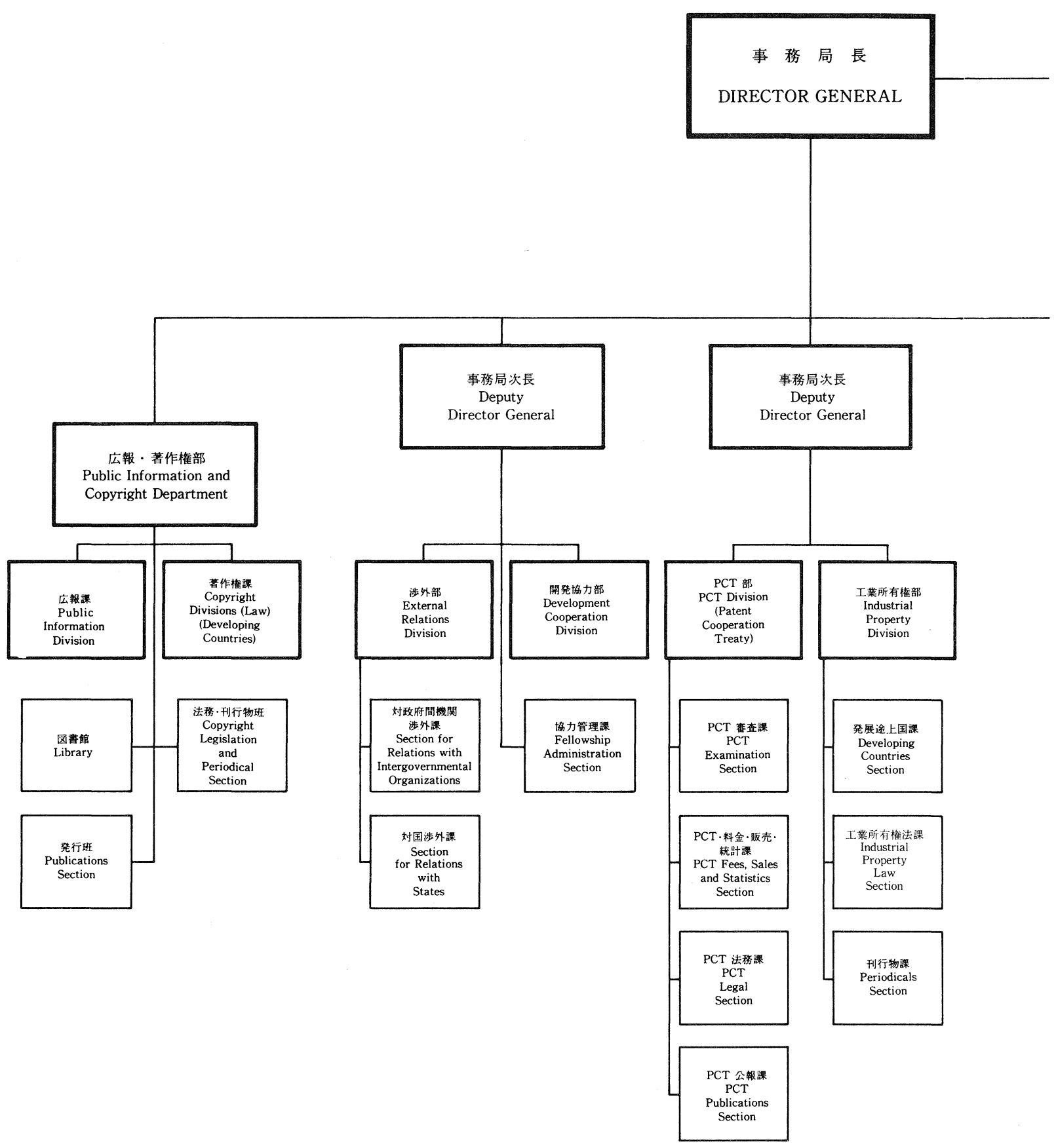



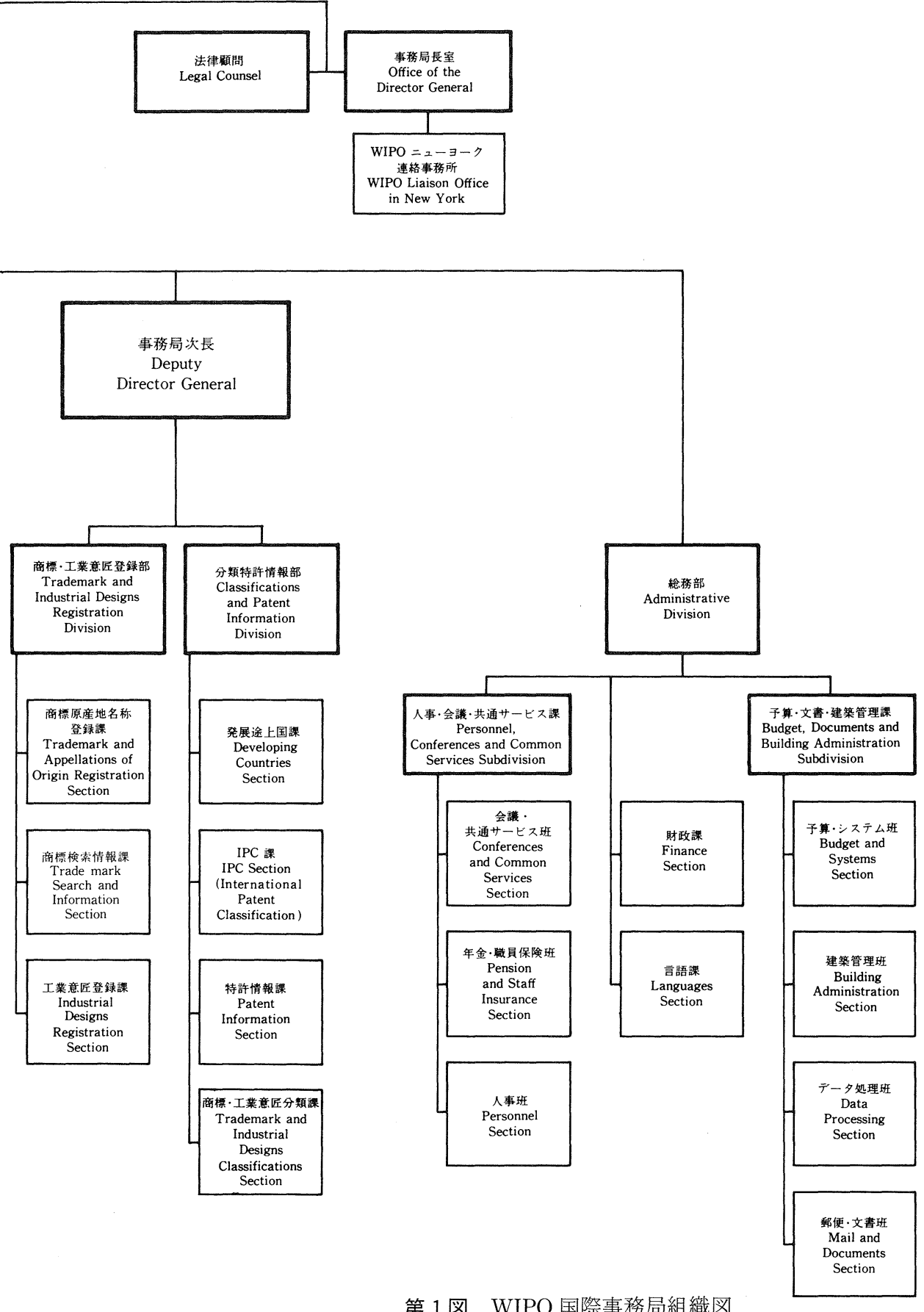

第 1 図 WIPO 国際事務局組織図 
ルヌ抽どその他の同盟の管理を委任されている ので，これら諸同盟の事務局でもある。

国際事務局は，WIPO に関しては一般総会抒よ び締約国会議に，また，パリ，ベルヌ扣よびその 他の幾つかの同盟に関しては, 各同盟の総会抒よ び代表者会議に参加する構成国により統轄され る。

パリ同盟抢よびベルヌ同盟はその構成国からそ れぞれ執行委員会を選出し，これら二つの委員会 の構成国で WIPOの調整委員会を構成する。

国際事務局は事務局長が指揮し，事務局次長が これを補佐している。国際事務局の常勤職員は, 1982年 3 月 1 日現在で約 50 か国の国籍の人から成 る約 270 名である。その身分は，国連の他の専門機 関の職員と同等である。

日本からも 3 名の職員 (いずれも特許庁審査官) が派遣され，重要なポストで活躍している。

第 1 図に国際事務局の組織を示す。

国際事務局は，WIPO 括よび諸同盟の種々の機 関の事務局として, 主として, 報告書と作業文書 を作成し，種々の機関の会議を準備する。それは 会議そのものを組織している。

会議の後は, 会議の決定がすべての関係機関に 伝達されたかどらか，また決定が実行されている かどうか監視する。

また，WIPO 掞よび諸同盟の権限むる機関と接 触を保ち，かつその監督の下に知的所有権の分野 に颃いて同盟国間の国際協力を推進するため新し い計画を企画し，また現在の計画を実施する。

\subsection{2 財政と予算}

国際事務局の主な財源は，加盟国からの分担金 と国際登録事業として徵収する手数料である。

分担金については, パリ, ベルヌ, ニース, ロ カルノ，技よび IPC 同盟の加盟国並びに前記いず れの同盟に加盟していなくても WIPOの加盟国 である国にとって義務的である。

登録手数料は, PCT, マドリッド, ヘーグ抢よ びリスボン同盟の国際登録事業により徵収される 料金である。

国際事務局の予算は 2 年単位となって扣り,
1982-1983年の 2 年間の予算は以下のと抒りであ る。 <収入 > 〈スイスフラン>

WIPO 分担金 250,000 パリ同盟分担金 $17,746,000$ ベルヌ同盟分担金 $8,422,000$ ニース同盟分担金 $1,095,000$ ロカルノ同盟分担金 250,000

IPC 分担金 $5,737,000$

PCT 分担金 $3,000,000$ UPOV 分担金 748,000 マドリッド同盟手数料 $17,378,000$ ヘーグ同盟手数料

$1,950,000$

$\mathrm{PCT}$ 手数料

$13,380,000$

その他

$5,084,000$ 総 計 $75,040,000$

<支出 $>$

職員

$45,983,000$

印刷

$3,263,000$

その他

$22,535,000$

総 計 $71,781,000$

\section{2、WIPOにおける情報活動}

国際事務局は知的所有権の保護に関するすべて の種類の情報を集中している。

情報の幾つかのものは，特別の請求があれば直 接その同盟国に提供される。

多くの情報はまとめられて, 英語とフランス語 の 2 種の月刊誌,「工業所有権 (Industrial Property)」，执よび「著作権 (Copyright)」，およびアラ ビア語，ポルトガル語，ロシア語およびスペイン 語で随時発行される時事ニュースに発表される。

これらの雑誌は, WIPO抢よび諸同盟の同盟 国，国際会議，各国法令の改正，国際事務局の事 業に関する情報，㧍よび知的所有権法の理論およ び実際的適用に関する論説等より成る。

第 2 図に「工業所有権(Industrial Property)」 を示す。 


\section{Industrial Property}
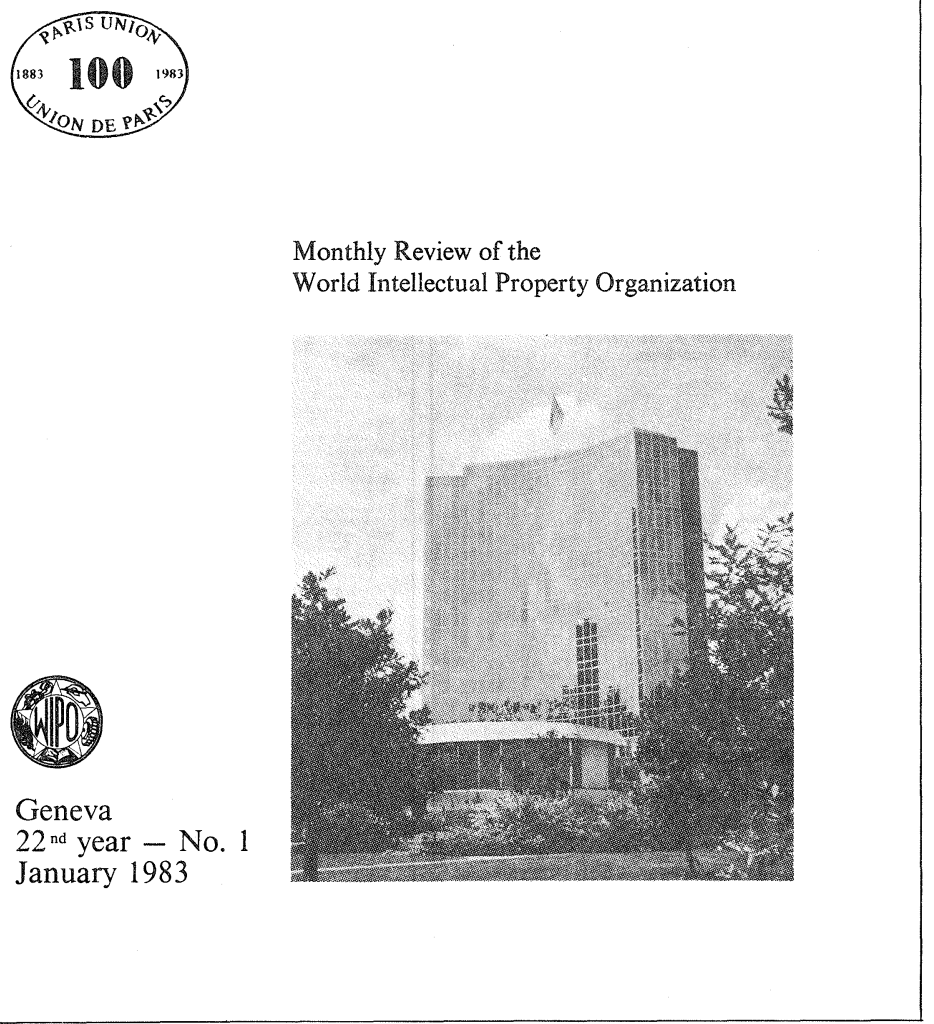

第 2 図 雑誌「工業所有権」の表紙
国際出願される発明 は, 出願人が複数の国に 预いて特許を取得しょう と意図しているものであ り,したがって，このパ ンフレットには高度かつ 重要な技術が多く含まれ ている。

パンフレットのサイズ はA 4 判であり, 明細 書, 図面, 国際調査報告 等が掲載され，さらに規 格化されたフロントペー ジが付されている。使用 言語は日本語, 英語, ド イッ語, フランス語, ロ シア語の 5 か国語であ り，この 5 か国語以外の 言語で国際出願された場 合は英語に翻訳されて公 開される。前記フロント ページには, 出願人, 発 明者等の書誌的事項, 要 約, 出願人が指定する図 面が一定のレイアウトで 掲載される。要約が英文 で公開されない場合に は，要約の英訳文があわ せて揭載される。

また，PCTに関連し

国際事務局は，また特許，商標，工業意匠，抒 よび原産地名称の各分野で以下のよらに国際登録 機関としての役割を果たして挹り，これらの業務 に伴い多くの重要な情報を公表している。

特許協力条約 (PCT : Patent Cooperation Treaty）に関しては，実質上中心的な行政的役割 を果たしている。すなわち同条約の下に提出され たすべての国際出願の記録原本をそのファイル中 に保存し, また, これらすべての出願を PCT 国際 公開パンフレットとして毎週公開している。
て, 国際特許出願ガゼットがパンフレットと同日 に発行されている。このガゼットは次の四つのセ クションから成り, 英語版, フランス語版で発行 される。

セクション 1 : 国際公開パンフレットのフロン トページの縮小版

セクション 2 : 国際公開後に遅れて提出された 国際調査報告書, 請求の範囲の補正等

セクション 3 : 出願人索引, 分類索引等の各種 索引 
セクション 4 : 各種機関の手数料等

第 3 図に, PCT 国際公開パンフレットのフロン トページを示す。

《特許協力条約 $(\mathbf{P C T})$ とは》

対外国出願に括ける出願人执よび特許庁の労力
重複の軽減と，発展途上国援助を目的とし，一つ の国際出願で複数の指定国に抢ける国内出願の効 果を発生させることを基本理念として設立され た。

この条約は1978年 3 月に発効し，1982年 3 月 1 日現在，日本を含む32か国が加盟している。

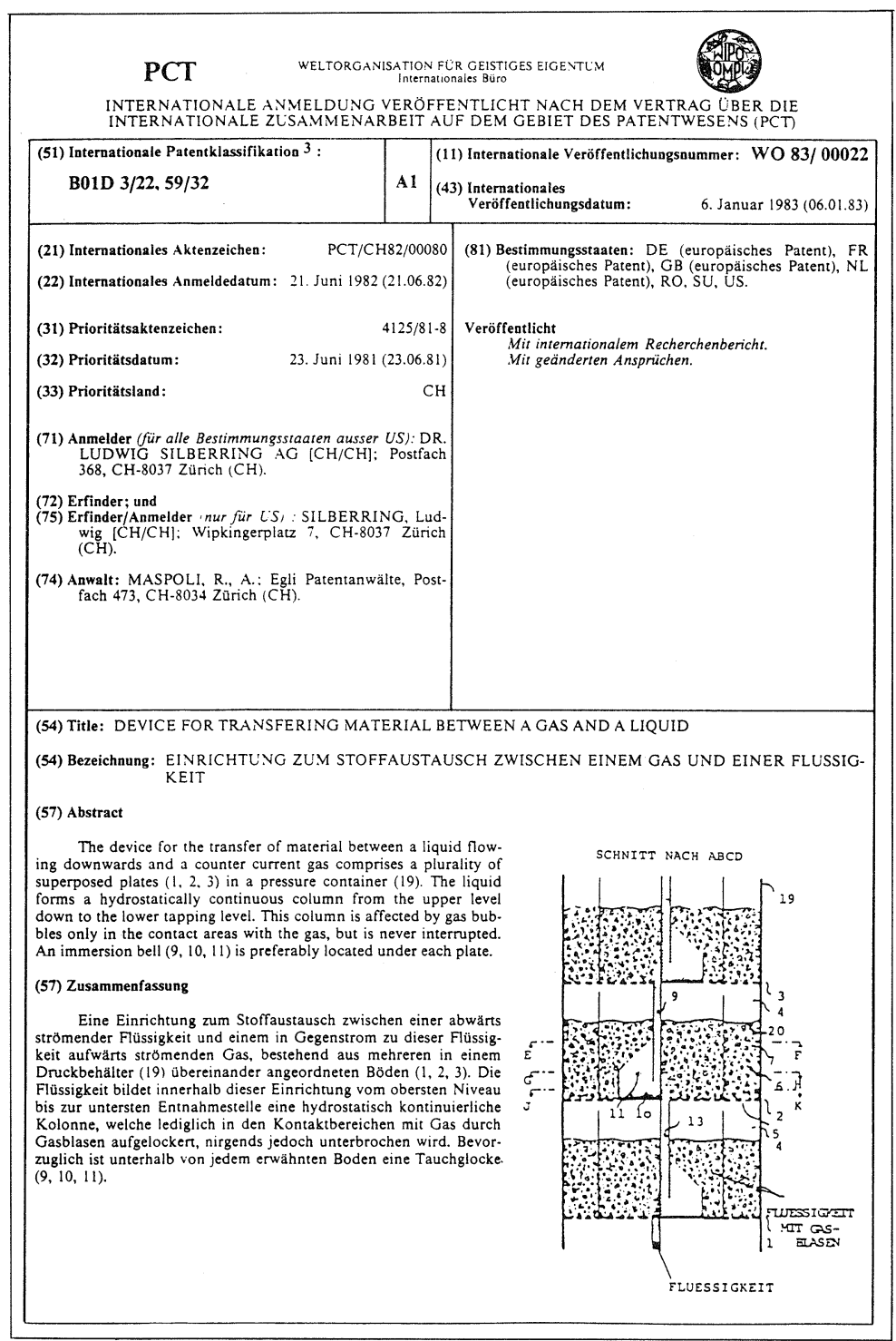

第3 図 PCT 国際公開パンフレットのフロントページ (出願人はスイス人で，ドイッ語で出願されているた め，英訳された要約が付されている）
従来の制度では, 権利 取得を望む国ごとに使用 言語を含めその国の方式 要件に従って出願書類を 作成し，かつ国ごとに異 なる出願手数料を添劣て 出願書類を提出しなけれ ば，その国に掞ける出願 の効果憕生しなかっ た。

しかし, PCT 国際出願 にあたっては，単一の言 語で，単一の受理官庁に 対し，一つの国際出願を するだけで多数国への出 願の効果を確保すること ができるようになった。 そして，すべての国際出 願は出願から18か月後に WIPO国際事務局によ り, 国際調査機関により 作成された当該発明技術 にかかわる国際調査報告 書と共に公表される。

商標の国際登録業務は 1893年以来存続してい る。すべての新しく登録 された商標, 登録の更新 および権利者の変更等に ついての情報は，月刊の 公報 (Les Marques Internationales）により 公表される。

工業的意匠の国際的供 
託業務は，1928年以来存続している。すべての新 しい登録および登録の変更については，2 種の言 語による月刊の公報 (International Designs Bulletin/Bulletin des dessins et modèles internationaux）に公表されている。

原産地の名称の国際登録業務は1966年から行わ れており，新しい登録がなされた時は公報（Les Appellations d'origine) を発行する。

WIPO の情報活動の中でも, 特許情報の分野に 拈ける国際協力はWIPOの主たるプログラムの 一つになっている。

産業, 経済の発達扣よび国際化の進展につれて 特許情報の重要性はますます高まって打り, 国連 貿易開発会議（UNCTAD）, 国連工業開発機関 (UNIDO), 開発のための科学技術国連会議 (UNCSTD) 等に扔いても，南北間に拈ける特許 情報問題が議題に上るなど, 特許情報問題が重要 視されるようになっている。

WIPO ではこのような特許情報問題の重要性 に鑑み,「特許情報に関する常設委員会 (PCPI : Permanent Committee on Patent Information)」 を設け, 従来は IPC 同盟, PCT 同盟等の各組織下 で行われていた特許情報に関する諸活動を, ここ で一括して行っている。

また，WIPO とオーストリア共和国との間の協 定に基づて, 国際特許ドキュメンテーションセ ンター (INPADOC : International Patent Documentation Center) が1972年にウィーンに設 立された。

INPADOC は，世界各国の特許情報を収集しょ らとする構想に基づき設立されたもので，その主 な業務は世界各国から収集した特許情報データを 加工し, INPADOC の特許情報サービスとして各 国特許庁，捛よび一般利用者にこれらのデータを 提供することである。

INPADOC は毎年約 100 万件の特許文献の書誌 データをコンピュータに入力し，これらのデータ を各国特許庁, 企業, 研究機関等に利用できるよ らにしている。

INPADOCにかかる経費負担と実行責任は
オーストリア政府にあり，WIPO は各国の特許庁 と接触することに関し, INPADOCを支援してい る。

INPADOC は現在, 世界49か国およびョーロッ パ特許庁 (EPO : European Patent Office), WIPO の 2 機関からのデータを約 950 万件蓄積し ている(1982年末現在)。これは世界の特許情報の $90 \%$ 以上に相当する。

日本特許庁も1972年にINPADOC と協定を結 び，データを交換している。また，INPADOCの 日本に拈けるサービスは, 日本特許情報センター (JAPATIC) が一手に行っている。

\section{3。WIPO の特許情報活動}

WIPO に执ける特許情報に関する活動は, 前述 の「特許情報に関する常設委員会」(以下 PCPI と 記す)に执いて一括して行われている。

特許情報は，工業所有権にかかる出願がなされ ることから派生する情報を中核として抢り，その 主体を成すものは各種特許公報類であり，世界に 沶いて年間約 100 万件の特許情報が生まれている。 一方, 技術開発の効率的促進, 開発成果の的確な 保護等のために，これら特許情報を有効に活用す ることの必要性が高まってきている。

これらの情況を踏ま光, PCPIは以下の事項に ついて各種同盟の当事者たる諸国, とりわけ, こ れらの国々の工業所有権庁および広域工業所有権 庁間の密接な協力をWIPO の枠内で確立し, 奨励 するために設立され，1979年よりその活動が開始 された。

（a）特許情報の一次および二次情報源の改善

（b）特許情報のアクセス手段の改善

(c) 特許文献および情報の国際交流

(d) 技術援助拀よび研修

PCPI のメンバーは, PCT 同盟の加盟国, IPC 同盟の加盟国，その他パリ同盟の加盟国で，メン バーとなる希望を表明にしたものから構成されて いる。現在58か国とヨーロッパ特許庁 (EPO) 抒 よびアフリカ知的所有権機構 (OAPI) の 2 機関が 


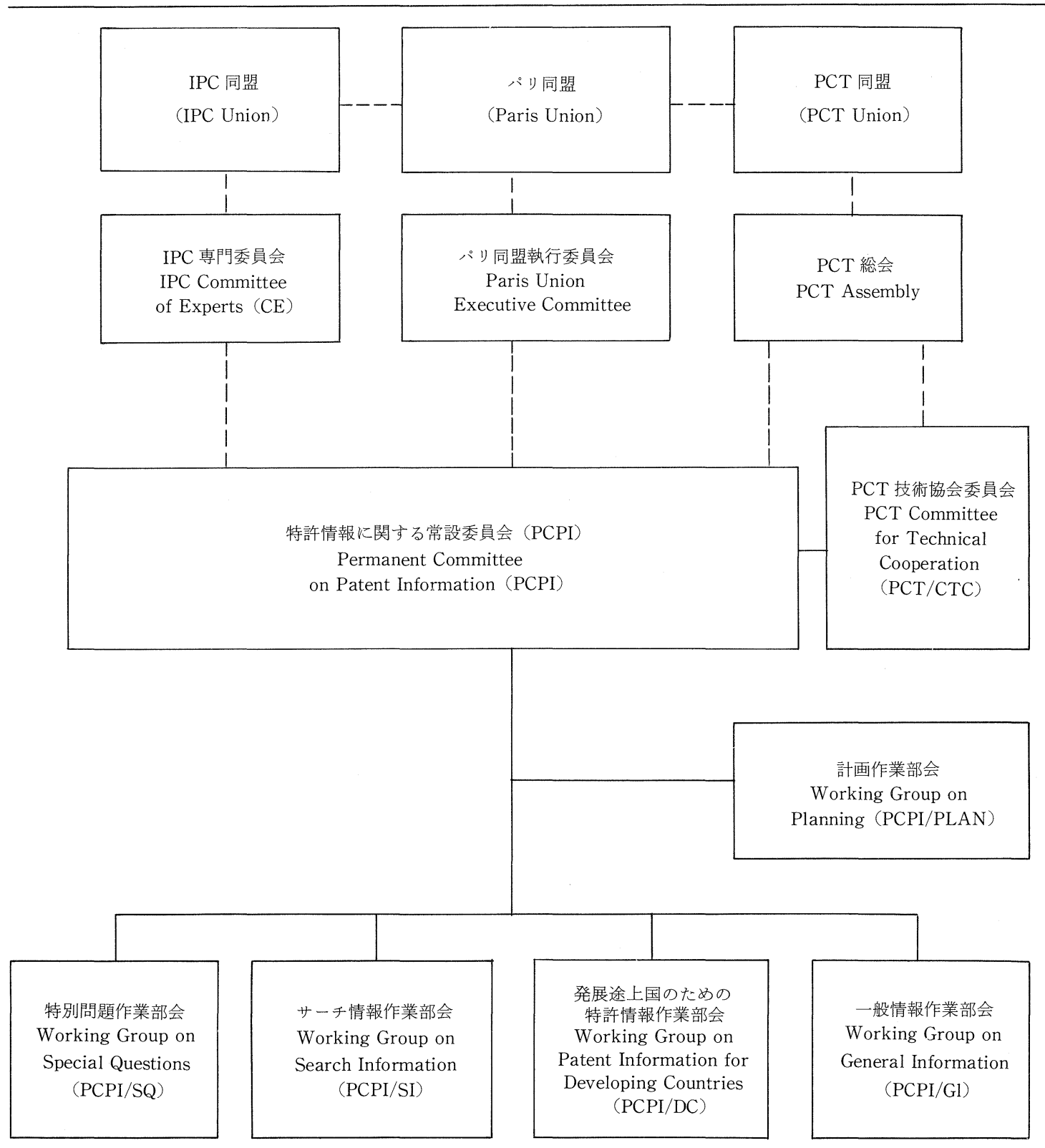

第 4 図 PCPI（特許情報に関する常設委員会）の構成

PCPIのメンバーとなっている。

PCPI の下には五つの作業部会があり, その構 成は第 4 図のようになっている。

このうち, 計画作業部会 (PLAN : Working Group on Planning）は他の作業部会と異なり,
PCPI の目的, 計画, 組織等について PCPI に勧告 し，また他の作業部会の活動に関しアドバイスを 行うことを主な業務としている。

以下, PCPI の活動を中心に, WIPO に抢ける特 許情報に関する具体的活動について紹介寸る。 


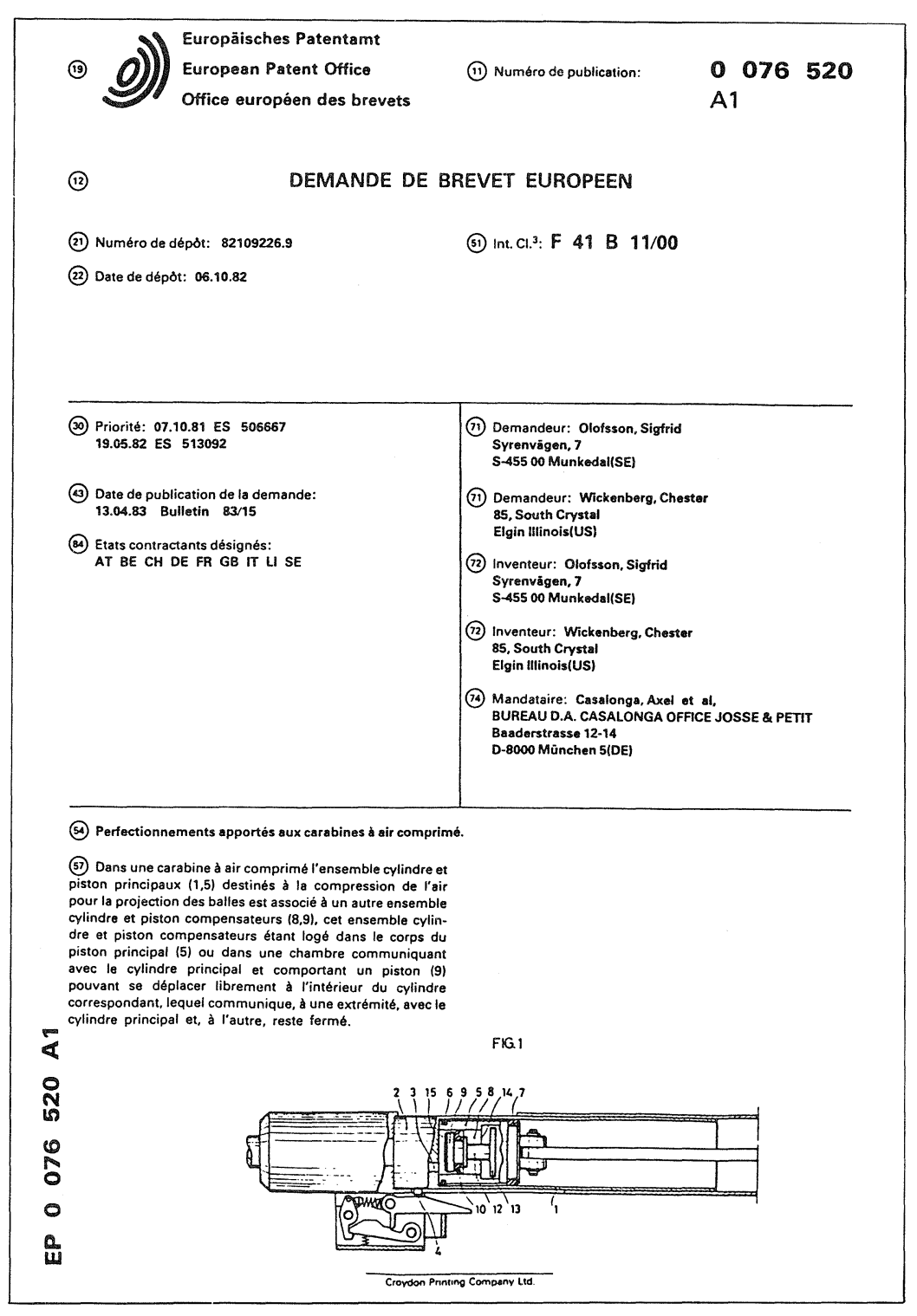

例光ば,
A $1 \cdots$ ー・レポートが添付された公開特許公報
(11)...文献番号
(22) …出願日
(57)...要 約
(71) …出願人名
Int. $\mathrm{CI}^{3} \cdots$ 国際特許分類 (IPC) 第 3 版
$\mathrm{F} 41 \mathrm{~B} 11 / 00 \cdots$ 国際特許分類 (IPC 記号
AT, BE, CH，国名コード（オーストリア，ベルギー，スイスを表す）

第 5 図 PCPI の標準を採用した特許文献( ヨーロッパ公開特許明細書から)

\section{1 特許情報源の改善} 特許情報は技術情報と しての価値に加光権利情 報としての価值を有し， ずべての技術分野がカ バーされ，乙かも浪涪同 一内容の書誌的事項（出 願人名，発明者名，発明 の名称，公表日等）が記 載されているため，先行 技術を調査するには非常 に有効な技術情報であ る。しかし，特許情報を 利用する場合，各国に よって言語，法制等が相 違するため, 円滑に利用 し得ない。そこで，この ような利用上の不便さを 克服し, 特許情報の有効 利用を促進させるため, 各国の協力による特許情 報の標準化の検討が PCPIの場で行われてい る。

特許情報の標準化と は，各国の言語，法制に 起因する特許情報関連事 項, 様式等の不統一から 生ずる諸問題を取り除 き，各国特許庁扮よび一 般利用者がそれぞれ特許 情報を有効に利用できる ようにすることを目的と して，特許文献上の書誌 的事項の表示, レイアウ ト，マイクロフォームあ るいは磁気テープ上の データのフォーマット等 の国際的な統一化を図る ものである。 
これら標準化に関する業務はPCPIの「一般情 報作業部会 (GIG : Working Group on General Information)」で行われて拉り, 多くの標準, あ るいはガイドラインが作成されている。

現在までに作成された主な標準あるいはガイド ラインとしては，書誌的事項識別のための国際的 合意番号 (INID コード…標準 ST. 9), 特許文献 の種類識別コード（標準 SI. 8), 特許文献の要約 作成に関するガイドライン（標準 ST. 12）等があ る。

これらの標準, あるいはガイドラインは, 特許 文献を発行しているほとんどの国に执いて受け入 れられている。これらの標準, あるいはガイドラ インを採用した特許文献を第 5 図に示す。

現在一般情報作業部会では, 各国が特許情報を 交換する際必要となる機械読み取り可能な形態 (例觉ば, 磁気テープ)での要約の標準化, 特許文 献に揭載される出願人名の表示を統一するための ネームインデックスに関する検討を行っている。

\section{2 特許情報のアクセス手段の改善}

\subsection{1 国際特許分類 (IPC : International Patent Classification)}

蓄積された膨大な特許情報の中から所望の情報 を選び出す手段が完全に備わっていなければこれ らの情報を利用でさない。

特許分類は，これらの情報を有効に利用するた めに作成されたものであり，発明の技術内容を把 握してその特徴を端的に示す指標として分類記号 を公報類に付与し，これによって検索（サーチ） を必要とする技術分野を選定し, 膨大な情報量の 中から目的とする情報を絞る（スクリーニング） ことができるようになる。このように，特許分類 は特許情報の整理, サーチに不可決, かつ重要な 役割を担っているが，多くの特許分類は各国独自 に作成され，その国の特許分類として利用されて きた。

しかし，近年のように国際間の技術交流が盛ん な中では，世界各国が独自の特許分類を有し，そ れを各々自国の特許文献に付与していたのでは,
外国特許文献を利用する場合は，その国の特許分 類の体系に習熟するか，あるいは自国特許分類を あらためて付与することを余儀なくされるため, 特許文献数の増加ともあいまって，外国特許文献 の利用時の負担が増しつつあった。

そこで，各国は国際的に統一された特許分類を 使用することを望むようになった。このような要 請にこたえ，世界各国が共通して採用することを 目的として，「国祭特許分類 (IPC : International Patent Classification)」が欧州評議会の下で作成 され，1968年 9 月 1 日に IPC 第 1 版が発効した。 そして，IPCをさらに国際化するため，1971年に 開催されたIPCに関するストラスブール外交会 議に和いて，「IPCに関するストラスブール協定」 が設立され，1974年10月 7 日に発効した。また， ストラスブール協定に基づき，IPC 同盟が設立さ れた。

IPC を使用することにより，世界各国の特許文 献についての共通の用語によるサーチが可能とな り，各国間で多大な負担となっていた言語上の障 害が軽減されることとなった。

IPC 同盟はパリ同盟の枠内で活動することと なって扣り，IPCの管理運営はWIPO の国際事務 局で行うようになっている。

IPC は 5 年に一度改正されることとなって物 り，現在1985年 1 月 1 日発効予定の第 4 版へ向け ての改正作業が進められている。

IPCの改正に関しては, PCPI が改正作業を行 い, その検討結果をIPC 同盟の専門家委員会 (CE : Committee of Expert) に勧告し, ここで 最終決定を行うこととなっている。

IPC 改正作業をはじめとして, IPC 関連事項は PCPIの「サーチ情報作業部会（SIG：Working Group on Search Information)」で扱われて抒 り,その他に, サーチファイルの構成あるいはサー チシステムの開発等についての検討作業が行われ ている。

現在の IPC 第 4 版へ向けての改正作業に掠い ては，ハイブリッドシステムの導入が検討されて いる。ハイブリッドシステムとは，特許文献に開 


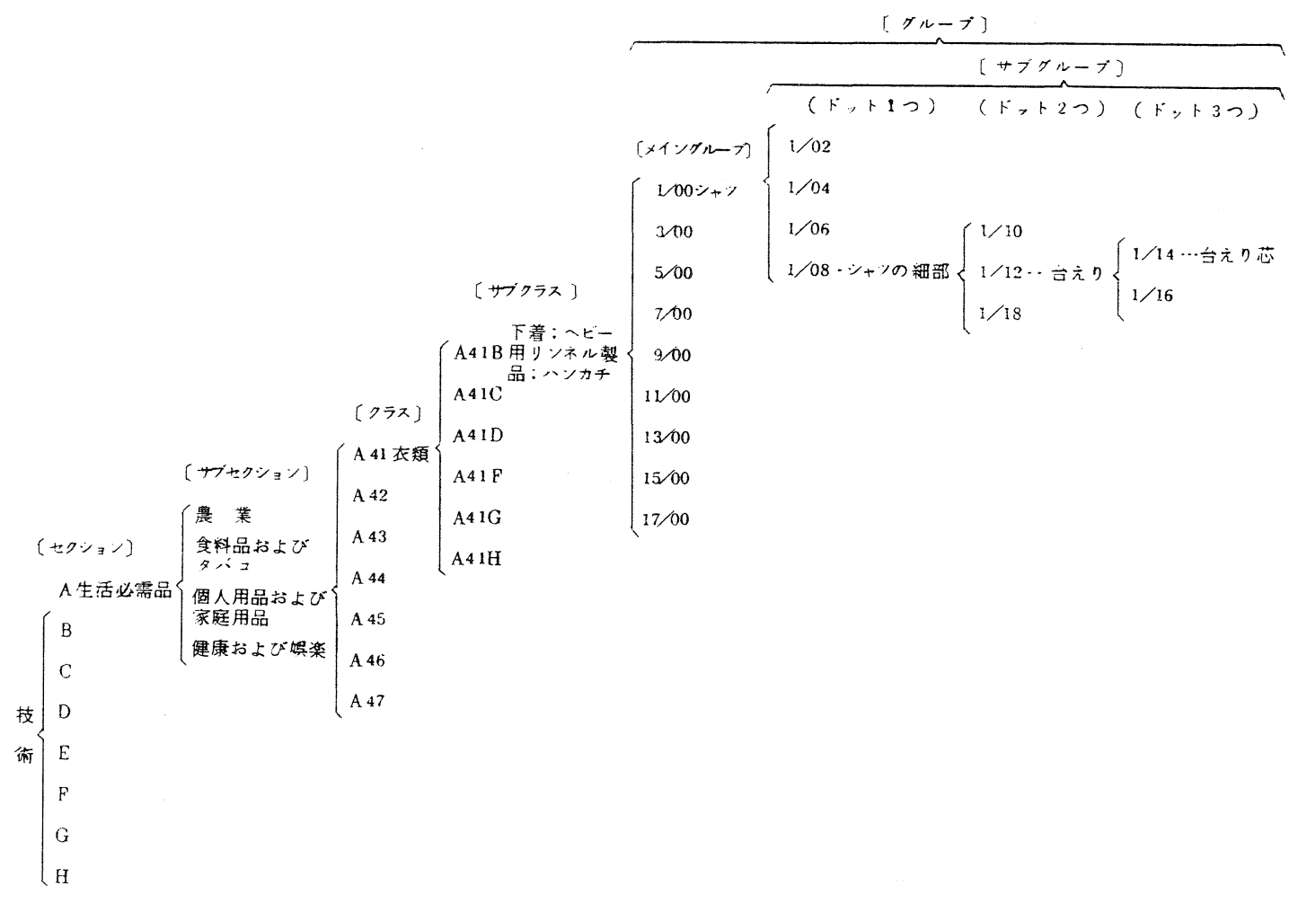

第 6 図 国際特許分類（IPC）の細分化関係

示された発明に，分類記号とは別の観点からも技 術の特徴を示す記号（インデキシング・ターム） を付与できるようにしようとするものである。

\section{《IPC の構成について》}

IPC は特許の対象となっているすべての分野 の技術を次の八つのセクションに分けている。
A 生活必需品
B 処理操作; 運輸
C 化学执よび治金
D 繊維掞よび紙
E 固定構造物
F 機械工学; 照明; 加熱; 武器; 爆破
$\mathrm{G}$ 物理学
$\mathrm{H}$ 電気
セクションは21のサブセクションに分けられて

いるが，これはタイトルだけで表示記号は与えら れていない。

サブセクションはさらにクラスに分けられて拉 り，2桁のアラビア数字で表される。

クラスはさらにサブクラスに分けられ，アル ファベット大文字で表される。

サブクラスはグループに細分化されて招り，一 次細分化によりできたグループをメイングループ と言い，メイングループを細分化したグループの ことをサブグループと言う（現在の IPC 第 3 版で

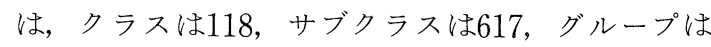
55,538 存在する)。

IPC の細分化の関係を第 6 図に示す。

\subsection{2 特許協力条約 (PCT) における最小限資 料}

特許協力条約に扔いては，世界的レベルに打け 
る新規性サーチの質を担保するため, 国際調査機 関（日本特許庁を含む世界 6 か国の特許庁および ヨーロッパ特許庁) が最小限サーチしなければな らない資料の範囲を規定している。これが PCT の最小限資料（Minimum Documentation）と言 われるもので, 以下の文献より成る。

<最小限資料>

(a) 特許文献

(1) 日本, アメリカ, イギリス, 西ドイッ, フ ランス, スイス(ドイッ語, フランス語), ソ連 の7か国に沶いて, 1920年以降に発行された特 許文献（ただし，公用語が日本語またはロシア 語でない国際調査機関は，日本とソ連の特許文 献については，英文要約のないものは資料に含 めないでよい。)

(2) PCT 出願公開明細書(国際公開パンフレッ ト), ヨーロッパ特許出願公開明細書, アフリカ 知的所有権機構特許発明明細書

(3) カナダ，オーストラリアの1970年以降に, およびオーストリアの1971年以降に発行された 特許文献であって，優先権主張を伴わないもの (b) 非特許文献

(1) 171種の技術雑誌

PCPI では，これら最小限資料にアクセスしゃ すいように目録を作成し，かつこれを更新してい る。李た，その他最小限資料にアクセスしやすい ように方策を検討し, PCT の技術協力委員会 (PCT /CTC : Committee for Technical Cooperation）に勧告している。

\section{3 発展途上国のための特許情報に関する援助}

特許情報の分野に抢ける発展途上国の二ーズを 取りまとめ，これらのニーズに合った方策に関す る提案を行らため, PCPI には「発展途上国のため の特許情報に関する作業部会（DC：Working Group on Patent Information for Developing Countries)」が設けられている。

ここではプログラムの一つとして発展途上国の 要請に応じ, 特定の技術に関して関連文献をサー チ収集し，その技術の水準を主として特許文献に
基づいて示したレポートを作成する「WIPO 技術 水準サーチプログラム」を実施している。このプ ログラムを利用して発展途上国は，必要とする特 定の技術の技術水準に関する情報を，主に特許文 献に基づき無料で得ることができる。

この作業部会で現在検討しているその他のプロ グラムとしては, 発展途上国が多く含まれている アラビア語, スペイン語执よびフランス語圏の 人々のために，特許文献の要約をこれらの言語に 翻訳するための外部資金を利用する可能性，ある いは発展途上国に扣いて, 特許情報センターを設 立するためのガイドラインの作成等がある。

\section{4 コンピュータ補助サーチシステム}

1981年11月12日に WIPO 本部に执いて, 特にコ ンピュータ,ビデオディスク执よび通信設備等の 技術の進歩に伴い，これらの技術がいかに特許審 査に利用され得るかその可能性をテーマとした， 各国特許庁首脳による PCPI サミット会合が開か れた。

出願審查に怙ける先行技術調査の対象となる審 查資料は, 特許文献だけでも世界中で年間約 100 万 件の割合で増えている。このような審査資料の増 大にいかに対処したらよいか，各国とも大きな関 心を持って和り，この膨大な審査資料の中から必 要な情報を効率よく取り出すための方策として, 最近, コンピュータ利用によるサーチシステムに 対し関心が高まってきている。

このような情況を受けて, PCPI サミット会合 に执いて、コンピュータ補助サーチシステムにつ いての討議が行われた。

この会合での討議の結果を受けて,コンピュー タ補助サーチシステムについて本格的にPCPIの 枠の中で検討することとなり，検討の場として新 たに「特別問題作業部会 (SQG : Working Group on Special Questions)」を設けることが，第 5 回 PCPI (1981,12) で決定された。

これを受けて特別問題作業部会が設立され，翌 1982年 4 月からここでコンピュータ補助サーチシ ステムについての検討が開始された。 
本件に関しては現在末でに，国際事務局がコン ピュータ補助サーチシステムの世界に括ける現状 について報告書を作成し，これについて作業部会 で検討を加えるとともに，日本特許情報センター (JAPATIC)，英国のダーウェント社をはじめ世 界の情報サービス機関拉よび工業所有権庁で稼働 しているシステムの紹介を行った。

以上，PCPI の活動を中心にWIPO に抢梳る特 許情報活動について紹介してきたが，これら PCPI の活動の成果は，「特許情報脑よびドキュメ ンテーションのための WIPO ハンドブック」(英 仏の 2 か国語で発行されている）にまとめられて いる。参考までにその目次を以下に示す。

《特許情報扣よびドキュメンテーションのため の WIPO ハンドブックの目次》

Volume 1

特許情報：国際協力

特許ドキュメンテーション：標準と勧告

Part 1：特許情報抒よびドキュメンテーショ ンに扔ける国際協力

Part 2 : PCT 最小限資料

Part 3 : 特許ドキュメンテーションに関する 標準 と勧告

Volume 2

国際特許分類 (IPC) : 特許サーチシステム

Part 4 : 国際特許分類（利用マニュアル）

Part 5：国際特許分類（改正手続）

Part 6 : 特許サーチシステム (IPC 以外)

Volume 3

特許ドキュメンテーション：調査，編集执よ び他の一般関連データ

Part 7 : 特許文献の種類々内容

Part 8 : 収納手段，複写执よび交換

Part 9 : 特許ドキュメンテーションへのアク セス

また，WIPO では各国の特許出願，登録件数等 の工業所有権に関する世界の統計情報を収集し, $「$ WIPO 工業所有権統計」として, 毎年発行してい る(英, 仏の 2 か国語)。

\section{4。発展途上国に対する援助}

PCPI 以外の場での WIPO の発展途上国に対 する援助の体制について，WIPO の案内書から引 用して以下に述べる。

\section{1 工業所有権}

工業所有権の分野に扮いては，WIPO は技術移 転を促進するため，「工業所有権に関するWIPO 開発協力常設計画」を設けている。この計画は, 発展途上国招よび工業先進国の69の代表から構成 されている常設委員会により監督されている。そ の目的は，発展途上国の技術能力を強化するため に発展途上国の発明活動や技術革新活動を促進, 奨励し，公正かつ合理的な条件の下に工業所有権 に関する技術の発展途上国による取得を容易に し，もって工業所有権の分野に拈ける発展途上国 の国内制度を強化することにある。

常設委員会は，その目的を遂行するための計画 を立て，さらに企画された特別な計画を実行する ための指針を与える。その特別な計画には発展途 上国が特許された技術を所有している外国人と交 渉したり，契約を結んだりする際に特別配慮しな ければならない問題を扱らセミナーの開催や出版 物の発行がある。

その他の計画としては，発展途上国のために特 に企画された発明，ノ一八ウ，商標，工業意匠特 よび原産地表示に関するモデル法の作成，最近の 発明に関する情報を含んだ外国特許文献の整備・ 収集，扣よびそのような特許文献の利用を図るた めの職員の研修に関する援助，さらには，工業所 有権拉よびそれに関連する法律を管理したり，ま た，それらの法律に基づく特許の付与抏よび商標 の登録を決定する政府機構の新設または近代化の ための援助がある。

\section{2 著作権・隣接権}

著作権扝よび隣接権の分野に招いては，WIPO は,「著作権及び隣接権に関する開発協力常設プロ ジェクト」を設定している。その目的は，文学的， 
学術的および美術的分野における知的創造活動を 発展途上国で奨励し, 創作者の権利 (著作権) 並 びに実演芸能人，レコード製作者执よび放送事業 者の権利 (隣接権) によって保護される文学的, 学術的拉よび美術的分野での知的創作物の発展途 上国に拈ける拡布を促進し, さらに，著作権执よ び隣接権の分野に関する発展途上国の国内制度の 強化に資することである。

このプロジェクトは発展途上国抒よび先進工業 国を含む53か国から成る常設委員会によって指導 されている。そして，それは，関係国政府に対し 著作権拉よび隣接権の分野に执けるあらゆる妥当 な発展協力活動を再検討するかっこうの場を提供 するばかりでなく，発展協力活動の策定やその実 行上の援助や指導を与光る役割を演じている。こ うして, 著作権や隣接権のモデル法, 関係する慣 行の解説書, 専門用語の解説書およびマニュアル 等が発展途上国のために作成された。その他, 著 作権によって保護されている著作物への発展途上 国のアクセスを容易にするため，UNESCO と協 同で国際サービス部門が設置された。

\section{3 研修}

WIPO は, 発展途上国の人々のために研修制度 を設けている。

この研修制度は, 発展途上国の研修生が特許, 商標, その他の形態の工業所有権抽よび著作権の 日常の管理業務についての実際の経験を修得する ためのものであり, 先進国の政府の工業所有権官 庁において研究したり, 研修を受ける機会を与え ている。

このような研修は, WIPOや国連開発計画 （UNDP）の費用または各先進工業国の援助によ る先進国から発展途上国への専門家派遣といら形 式をとることもある。

WIPO は, また，工業所有権および著作権の分 野に打ける最近の問題点について意見交換し，討 議するため, WIPO の費用により発展途上国の代 表を招聘し, 毎年地域セミナーを開催している。

\section{WIPO の出版物}

WIPO の全出版物は WIPO 本部で販売されて 招り, WIPO 出版物の完全な一覧表は請求すれば 入手できる。

注文は WIPO 本部 (34, chemin des Colombettes, 1211 Geneva 20, Switzerland）に送付すると ともに，出版番号を明示する。

以下に WIPO 出版物の概要を記す。

(1) 雑誌

"Industrial Property"

"Copyright"

“PCT Gazette”等

(2) 条約括よび協定の本文

(i) 知的所有権 世界知的所有権機関設立条約 等

(ii) 工業所有権

工業所有権の保護に関するパリ条約

国際特許分類に関するストラスブール協定 商標登録条約 等

(iii) 植物新品種 植物新品種の保護に関する条約

(iv) 著作権

文学的抒よび美術的著作物の保護に関するべ ルヌ条約 等

(v) 隣接権

実演家，レコード製作者执よび放送事業者の 保護に関するローマ条約 等

(3) 国際分類

(i) 特許

国際特許分類掞よび公定キャッチワードイン デックス

(ii) 標章

商標のための商品执よびサービスの国際特許 分類 等

(iii)工業的意匠

工業的意匠のための国際分類

(4) モデル法

(i) 工業所有権

発明に関する発展途上国のための BIRPI モ 
デル法 等

(ii) 著作権

著作権に関する発展途上国のためのチュニス モデル法

(iii) 隣接権

実演家，レコード製作者执よび放送事業者の 保護に関するモデル法

(5) その他

発展途上国のための実施許諾契約案内

PCT 出願人の手引

コンピュータ・ソフトウェアの保護に関するモ デル規定

工業所有権用語小辞典 等

\section{6.おわりに}

技術はますます高度化, 複雑化している。また， 技術, 経済の国際化が進久, 先端技術に抢ける競 争も一段と激しくなりつつある。また, 文化, 芸 術等の分野でもますます国際交流が盛んになって いる。このような情況の中で, 工業所有権扔よび 著作権に対する認識は今後ますます高まっていく であろう。そして，この二つの権利の国際的保護 の促進を目的として活動しているWIPOの重要 性は一段と高まっていくと思われる。

特許情報について言えば，既に述べたように世 界で年間100万件の特許文献が発行されて和り, こ れらの特許情報には世界の重要かつ先端技術がす ベて含まれていると言っても過言ではない。これ をどのように有効利用できるようにするかが， WIPO および各国特許庁等に課された課題であ 万弓。

その中でも，日本は世界の特許文献の約 $40 \%$ を 発行している。これは日本に抢ける技術開発の活
発さを示していると言える。また，日本の高度な 技術レベルを反映して重要な特許情報として世界 の関心を集めている。したがって，WIPO の活動 に招いても特許情報に関する種々の検討が PCPI の場で行われていることは既に述べたと拉りだ が，ここでは日本の発言が非常に重みをもって受 け止められている。

また，増光続ける膨大な情報にいかに対処した らよいかについて，WIPO の場で険討を開始して いる。この点に扔いても, 日本は米国, ヨーロッ パ特許庁と共にコンピュータ補助サーチシステム の検討等この問題の解決に向けてリードしていく 役割を期待されている。

一方，最近，コンピュータのソフトウェアの保 護をいかに行らかについて関心が高まっている。 WIPOに执いては，この件についても検討を進め て打り，本年 6 月にコンピュータ・ソフトウェア の法的保護に関する専門委員会が開催された。こ こでは，(1)コンピュータ・ソフトウェアの法的保 護に関する新条約草案, (2)コンピュータ・ソフト ウェアの国際的寄託制度, (3)集積回路の保護につ いて検討が行われた。これらの問題についてはま だ緒についたばかりで, 今後の検討が待たれる。

今後, 科学技術, 情報, 文化, 芸術等の活動物 よび国際間の交流が活発となるに従い，ますます 広範な活動が期待されるWIPOへの理解に関し て，本稿が少しでも役立つこととなれば幸いであ る。

\section{参考文献}

1) WIPO General Information, Geneva, 1982/ 1983

2) WIPO Patent Information and Documentation Hand Book

3 ) PCPI 会合 各作業部会等のレポート 